\title{
PENGALAMAN HIDUP ORANG DENGAN HIV/AIDS (ODHA) DI KELOMPOK DUKUNGAN SEBAYA KOSALA BALI
}

\author{
Made Suastrawan', Gede Budi Widiarta², Ni Made Raningsih ${ }^{2}$ \\ Program Studi Ilmu Keperawatan Sekolah Tinggi Ilmu Kesehatan Buleleng
}

\begin{abstract}
Abstrak
Pendahuluan : AIDS (Acquired Immune Deficiency Syndrome) suatu penyakit yang menyerang sistem kekebalan tubuh manusia menjadi lemah akibat virus HIV . Tujuan: Tujuan dari penelitian ini adalah untuk mengetahui pengalaman hidup orang dengan HIV/AIDS (ODHA) di KDS Kosala Bali. Metode: Jenis penelitian ini adalah menggunakan desain kualitatif dengan pendekatan fenomenologi yang dilaksanakan di Kelompok Dukungan Sebaya Kosala Bali, Desa Kaliasem. Pengumpulan data ini menggunakan teknik wawancara mendalam (In-depth Interview) dengan jumlah partisipan 6 orang. Hasil : Dari penelitian didapatkan 6 tema dalam penelitian ini, diantaranya (1) Kesedihan serta perasaan takut meninggal yang dirasakan saat mengetahui penyakit yang dialami, (2) Bentuk deskriminasi dan pengucilan dari keluarga serta lingkungan masyarakat, (3) Penerimaan dan dukungan dari masyarakat terhadap penyakit yang dialami, (4) Perasaan putus asa dalam menjalani terapi, serta efek samping yang ditimbulkan dari obat ARV, (5) Mekanisme koping positif untuk menjalani hidup setelah terkena penyakit yang diderita, (6) Sikap tertutup yang serta kegiatan yang dilakukan untuk melupakan penyakit yang dialami.
\end{abstract}

Kata kunci : HIV/AIDS , kesedihan, terapi ARV, deskriminasi.

\begin{abstract}
AIDS (Acquired Immune Deficiency Syndrome) a disease that attacks the human immune system becomes weak due to the HIV virus. The purpose of this study was to find out the life experiences of people with HIV / AIDS (PLWHA) in KDS Kosala Bali. The type of this study was to use a qualitative design with a phenomenological approach carried out at the Sebaya Kosala Bali Support Group, Kaliasem Village. This data collection uses the technique of in-depth interviews with the number of participants of six people. From the research found 6 themes in this study, including (1) Sadness and feeling of fear of death that is felt when knowing the disease experienced, (2) Form of discrimination and exclusion from family and community environment, (3) Acceptance and support from the community for diseases experienced, (4) Feelings of hopelessness in undergoing therapy, as well as side effects caused by ARV drugs, (5) Positive coping mechanisms to live life after being exposed to the illness, (6) Closed attitudes and activities to forget about illnesses experienced
\end{abstract}

Keywords: HIV / AIDS, sadness, ARV therapy, discrimination.

PENDAHULUAN

AIDS (Acquired Immune

Deficiency Syndrome) suatu penyakit yang menyerang sistem kekebalan tubuh manusia menjadi lemah akibat virus HIV. (Sarikusuma, Herani, \& Hasanah, 2012) menyatakan bahwa HIV (Human Immunodeficiency Virus) suatu virus yang menyerang sistem kekebalan tubuh dan 
melemahkan kemampuan tubuh. Virus ini biasanya ditemukan dalam cairan tubuh seperti air mani, darah, cairan vagina, serta air susu ibu.

Menurut WHO (2016), secara global sebanyak 17 juta dari 37 juta orang ODHA yang telah hidup dengan HIV. Dan 22 juta lainnya tidak mengakses terapi antiretroviral diperkirakan sebanyak $70 \%$ orang yang hidup dengan HIV berada di negara berkembang termasuk negara Indonesia. Masalah fisik yang di alami ODHA adalah rentan terkena penyakit infeksioportunistik baik oleh virus, bakteri maupun jamur.Di indonesia ODHA sering kali mendapat diskriminasi dari masyarakat lainnya karena dianggap ODHA adalah pembawa virus yang dapat menular dalam hal apapun (Gusti \& Farlina, 2015)

Komisi penanggulangan AIDS di daerah Kabupaten Buleleng mencatat jumlah kumulatif penderita AIDS dari tahun 1999 sampai 2013 tercatat sejumlah 1673 orang terinfeksi HIV/AIDS. Jumlah laki-laki ODHA sebanyak 1057 orang dan jumlah wanita ODHA sebanyak 616 orang. Golongan umur yang terbanyak penderita HIV/AIDS yaitu dari umur 20 tahun sampai 29 tahun yaitu sejumlah 722 orang ODHA dan akan terus mengalami peningkatan, karena kasus HIV/AIDS sering diartikan seperti sebuah fenomena gunung es, jumlah yang sebenarnya penderita HIV/AIDS diperkirakan jauh melebihi jumlah yang tercatat .

Menurut KDS Kosala Bali (2017), jumlah penderita HIV/AIDS yang tercatat satu tahun terakhir yaitu sebanyak $2.703 \mathrm{di}$ seluruh Kabupaten Buleleng. Total dari keseluruhan kelompok wanita yang didampingi oleh KDS Kosala Bali yaitu sejumlah 345 wanita ODHA diantaranya wanita yang belum menikah sejumlah 14 orang dan ibu rumah tangga sejumlah 266 orang, sedangkan laki-laki ODHA yang didampingi oleh KDS Kosala Bali sebanyak 425 orang, diantaranya laki-laki yang belum menikah sebanyak 18 orang dan yang sudah berkeluarga 407 orang. Berdasarkan uraian fenomena pada latar belakang diatas maka peneliti ingin meneliti tentang " Pengalaman hidup orang dengan HIV/AIDS (ODHA) di KDS Kosala Bali “

\section{METODE}

Penelitian ini menggunakan tehnik kualitatif dengan pendekatan studi fenomenologi. Pada buku (Creswell, 2014) Fenomenologi merupakan pandangan berfikir yang menekankan pada fokus pengalaman-pengalaman subjektif manusia dengan suatu rangkaian kegiatan untuk memeperoleh data yang bersifat fakta dan apa adanya yang dilakukan melalui wawancara mendalam (indepth Interview).

Penelitian ini dilaksanakan di Kelompok Dukungan Sebaya Kosala Bali tepatmya di Desa Kaliasem, Kecamatan Banjar, Kabupaten Buleleng-Bali , dari bulan April 2019 sampai dengan bulan Mei 2019. Partisipan yang digunakan dalam penelitian ini adalah sebanyak 6 orang, partisipan tersebut adalah anggota dari komunitas waria tersebut.

Penelitian ini dilakukan di kantor Yayasan KDS Kosala Bali, yang beralamat di Banjar Dinas Lebah, Desa Kaliasem, jadi pemilihin lokasi tersebut sesuai kesepakatan antara peneliti dan partisipan.

Sebelum melakukan penelitian , peneliti melakukan pendekatan dengan partisipan, sehingga terbentuknya hubungan saling percaya, setelah itu peneliti membuat jadwal pertemuan dengan partisipan sesuai dengan kesepakatan. Setelah itu, peneliti melakukan wawancara berdasarkan waktu yang telah disepakati. Alat pengumpulan data yang digunakan berupa catatana kecil, rekaman recorder, pedoman wawancara. Setelah itu peneliti melakukan pengolahan data dengan cara mendengarkan remakan audio recorder kemudian dibuatkan transkip wawancara dan mencocokan data yang diperoleh. Setelah yakin data dari partisipan tersebut sudah lengkap, peneliti akan melakukan wawancara dengan partisipan selanjutnya. Kemudian peneliti melakukan koding dengan mengelompokan dari kategori menjadi tema, setelah itu akan dikelompokan lagi menjadi sub tema, yang dikelompokan berdasarkan tujuan. Setelah itu peneliti 
membahas berdasarkan hasil koding yang telah di peroleh.

\section{HASIL DAN PEMBAHASAN}

a. Tema 1 : Kesedihan serta perasaan takut meninggal yang dirasakan saat mengetahui penyakit yang dialami

Perasaan sedih, kaget dan syok saat mengetahui postif $\mathrm{HIV}$

P2 : "Perasaannya? Eeemmm perasaanya sedih saya kena ee positif itu Cuma untungnya ya bidan banjar itu hebat aku akui itu, kan saya diperiksa dulu, dibilangan mau ambil test positif sama negatifnya tu, saya kesana, didudukin dah, yee be keto saya diginiin, gini-gini pak, nanti kalau bapak itu saya ceritaain semuanya, kalau bapak negative, jangan ketawa-ketawa, kalau bapak positif jangan nyesel jangan minum apa apa digituin kan"

P6 : "Terus saya cek kesini, ternyata baru dilihat memang saya kaget terus terang saya kaget, karena terus terang saya syok dengan penyakit ini (klien menangis).. ... jujur suami saya enggak terima dengan penyakit ini , dia enggak percaya terus keluarga saya semuanya syok"

P4: "Kagett jelas inggih, Inggih jelass tyang sedih inggih, soalne tyang kan hidup tyange di kubu, tyang yen tyang merantau ngajak adik, tau-taunya setelah kenten, postifnya nike tyang tahu setelah tyang pisah ajak kurnan tyange." Kesimpulan dari pernyataan partisipan adalah bahwa mereka merasakan sedih, kaget serta syok saat mengetahui dirinya terinfeksi HIV. Bahkan, tidak bisa dipungkiri bahwa perasaan seperti ini akan dirasakan oleh semua ODHA, karena HIV dianggap penyakit yang paling mematikan baginya.

Perasaan menyesal dan marah terhadap penyakit yang dialami

P1 : "Kalau dulu mungkin baru baru tau itukan marah, marah-marah sama Tuhanlah kenapa saya begini gitukan, sedangkan saya itu anggaplah tidak negative gitukan" P4: "Yen menyesal nike pasti inggih, napi mawinan sakite seperti ini, kok bisa, nyesel jelas nyesel tapi nyesel mau bagaimana lagi

harus bangkit udah ada arahan, udah ada relawan yang udah semangat."

Kesimpulan dari pernyataan partisipan adalah bahwa partisipan juga merasakan marah serta menyesal terhadap penyakit yang dialami, perasaan ini muncul karena kebiasaan buruk yang dilakukan serta ada juga yang mendapat penyakit ini karena ditularkan oleh suaminya.

Perasaan sedih, kecewa dan rasa tidak nyaman saat mendapat tekanan dari keluarga serta masyarakat

P6: "Makanya kadang rasa kecewa itu pasti ada, keluarga membalik menjauh sama saya apalagi orang-orang yang tahu kan kesana jadinya pikirannya, kesannya itu udah jelek gitu sampai anak aja disuruh menjauh, apalagi orang-orang makanya tak diemin aja" P1: "Saya sendiri risih tapi gak tau orang dan orang lain juga gimana gitu tapi saya risih gitu, Diusirsih gak, cumin begini eemmm...gimana yaa caranya dia melihat saya itu kurang enak gitu dan duduk berdekatan gitu gak mau saya duduk sini dia pergi gitu dia menjauh gitu ngusir sih gak gitu cumin saya karena gitu gitu dah kakakknya yang terlalu keras gitu akhirnya saya keluar dari rumah",

P2: "Kalau perasaan takutnya sihh, pasti ada cuman adanya satu, kalau saya itu sakit drop, kadang-kadangkan bisa obat nanti bilangin gini, bilangin gitu, kalau enggak ada obat kan itu yang saya takuti, nanti obat enggak ada cuman takutnya meninggal dah, pasti takutnya meninggal karena obat enggak ada, kalau obat masih ada ngapain saya takut, yang penting ada obat, yang penting rutin minum obat"

Pada penelitian (Risnawati, 2018) mengungkapkan bahwa ada dua respon psikologis yang ditimbulkan pada penderita HIV/AIDS, diantara respon denial dan respon acceptance. Respon denial adalah reson menolak terhadap penyakit yang dialami, biasanya partisipan akan memberikan respon sedih, stress, emosional, dan berduka, sedangkan respon acceptance 
adalah respon penerimaan pada penyakit yang dialami, biasanya klien akan merasa pasrah terhadap penyakit yang dialami.

HIV/AIDS dianggap sebagai hukungan mati bagi setiap ODHA, biasanya orang pertama kali terdiagnosis HIV dan AIDS sering kali merasa depresi, stress, putus asa, bahkan takut untuk meninggal. Dalam kondisi seperti ini biasanya orang terkena HIV/AIDS akan merasakan keterpurukan dalam menjalani hidupnya

b. Bentuk deskriminasi dan pengucilan dari keluarga serta lingkungan masyarakat

Bentuk deskriminasi atau pengucilan dari keluarga

P2: "Yaaa, kalok pertama saya habis kelihatan HIV yaa, semuanya kalok keluarga itu membuang, saya hampir nangis"

Bentuk deskriminasi atau pengucilan dari masyarakat

P3 : "Pokoknya diomongin saya kemana-mana saya kan setelah meningeal suami saya bikin usaha buat kue saya taruh dah di warungwarung itu kalau ada yang tahu dia sakit gitu ada endak yang mau beli kuenya"

Kesimpulan dari pernyataan partisipan bahwa partisipan mendapat deskriminasi atau pengucilan dari keluarga dan masyarakat karena dianggap membawa virus oleh masyarakat

Setiap orang yang terkena penyakit HIV bukan hanya perasaan mereka saja yang sedih ketika mengetahui tentang penyakitnya, namun mereka juga harus menerima pengucilan ataupun deskriminasi dari keluarganya sendiri maupun dari lingkungan masyarakat.

Kata deskriminasi dan pengucilan tidak pernah jauh dari kalangan ODHA, setiap ODHA akan mengalami hal tersebut, dskriminasi tidak hanya dari kalangan masyarakat bahkan sangat disayangkan deskriminasi juga didapat dari keluarganya sendiri.
Dalam penelitian (Nur, Hasanah Hasna, \& Ika, 2012) mengungkapkan bahwa deskrminasi mengandung artis perlakuan yang tidak seimbang terhadap sekelompok orang, yang pada hakektnya adalah sama dengan kelompok pelaku deskriminasi. Deskriminasi terhadap ODHA sangat sering terjadi khususnya dalam hal pergaulan di masyarkat bahkan dilingkungan keluarganya sendiri.

c. Tema 3 : Penerimaan dan dukungan dari keluarga dan masyarakat terhadap penyakit yang dialami

\section{Bentuk penerimaan dan dukungan dari keluarga terhadap penyakit yang dialami \\ P6: "Enggak pernah ngurung diri saya cuman pikirannya gitu dah karena kluaraga terutama yang mendukung disuruh berobat semua penyakit pasti ada obatnya"}

$P 3$ : "Bergaul biasa saling mengingatkan sehat, udah minum obat, mengingatkan dia mengingatkan gimana sehat, udah minum obat"

P2 : "Aku diomongin, lebih baik aku yang terbuka.Terbuka sayaa, saya kemana-mana tadi aja saya orang tukang disini itu saya ceritain, eemm saya gini bapak jangan eemm gini pak karena saya itu udah HIV gitu, semuanya aku terbukain, dari pada saya ditakutin lebih baik saya cerita dulu kalok dia memang takut dia biar dia mengundurkan diri dah"

Bentuk penerimaan dan dukungan dari keluarga dan masyarakat terhadap penyakit yang dialami sangat diperlukan karena dengan penerimaan dan dukungan yang didapat maka akan membuat untuk semangat dalam menjalani kehidupan.

Peningkatan harapan hidup bagi ODHA membutuhkan suatu dukungan dari keluarga maupun masyarakat, dalam hal ini dapat memicu semangat hidup bagi setiap individu yang mengalami HIV/AIDS, setiap bentuk dukungan yang diterima 
akan selalu menimbulkan hal postif bagi kehidupan ODHA.

Dalam penelitian

(Rahakbauw, 2016) mengungkapkan bahwa dukungan sosial merupakan suatu bentuk dukungan bantuan dari lingkungan sekitar individu yang dianggap dekat secara emosional, dan berfungsi memberikan kenyamanan fisik dan psikis. Dalam hal ini, jika setiap individu mengalami stress terhadap suatu masalah, dukungan sosial dari lingkungan sekitar sangat dibutuhkan oleh ODHA tersebut. Bentuk-bentuk dukungan yang didapat biasanya berupa dukungan emosional, dukungan penghargaan, dukungan materi, serta dukungan informasi, setiap dukungan tersebut sangatlah bermanfaat bagi kelangsungan hidup ODHA.

\section{d. Perasaan putus asa dalam menjalani terapi, serta efek samping yang ditimbulkan dari obat ARV}

P3: "Awalnya itu muntah-muntah kalau saya reaksinya saya, kalau saya, seperti orang ngidam itu lohh mual muntah, pusing, aaaddduuuhh luar biasa selama 6 bulan itu saya kayak gitu terus tremor, eeemmm, kayak biulan kalau bali itu lohh, kakinya kejang gitu tiba-tiba, iiihhh pucet pokoknya. Makan muntah, luar biasa itu pucet dah pokoknya endak bisa, habis minum obat langsung tidur malamnya itu kan 2 kali itu pagi sama malem, selama 6 bulan kalau enggak salah"

P6: "Kadang pernah sih, kadang saat ini dah, kadang pada saat ada masalah sama suami, kadang males dah minum obat, pernah sering punya fikiran kayak gitu, tapi kebalik lagi, biss kasian juga anak-anak, kadang sering buk komang yang bilang, enggak boleh putus obat, harus teratur, jam harus tepat"

Terapi obat ARV adalah suatu keharusan bagi setiap ODHA, karena obat ini bisa menekan virus yang telah berkembang ditubuh seorang ODHA. Terapi ARV tidak dapat membunuh virus dalam tubuh, hanya saja dapat menekan atau memperlambat laju pertumbuhan virus, sehingga seseorang harus mengkonsumsi ARV seumur hidup dan tepat waktu, hal ini dapat menimbulkan perasaan putus asa dalam mengkonsumsi obat seumur hidup

Dalam penelitian (Yuniar, Handayani, \& Aryastami, 2011) mengungkapkan bahwa terapi ARV merupakan terapi seumur hidup, maka masalah kepatuhan terapi merupakan masalah umum pada setiap ODHA. Penyebab ketidakpatuhan oleh ODHA antara lain karena efek samping samping yang mungkin muncul dalam mengkonsumsi ARV, diantaranya mual, pusing, gatal, dan lain sebagainya

Dalam penelitian (Handayani, 2017) mengungkapkan bahwa orang dengan HIV/AIDS (ODHA) untuk mengikuti atau tidak terapi ARV tergantng perceived severity yaitu persaan tentang serius atau tidaknya penyakit yang diderita. Kebanyakan ODHA yang berum terap ARV adalah ODHA yang belum mengalami IO HIV yang serius seperti TB atau Hepatitis, jadi kebanyakan ODHA yang tidak mau terapi ARV karena masih merasa sehat.

e. Mekanisme koping positif untuk menjalani hidup setelah terkena penyakit yang diderita

P1 : "Karena mungkin kalau saya enggak terkena penyakit ini saya santaikan, udah ada mertua gitu, kalau saya terkena penyakit begini, saya mikir umur saya enggak panjang lagi, nanti gimana masa depan anak saya gitu, saya sekarang harus kerja keras biar kedepannya anak saya bias jadi orang sukses"

P5: "Saya kepingin melihat mereka tumbuh dewasa, punya anak cucu, jangan sampai, saya sudah terpuruk, dia juga ikut terpuruk, saya liatnya anak, karena bagaimanapun juga saya sebagai orang tua, pinginnya yang terbaik untuk anak, 
Jurnal Kesehatan MIDWINERSLION

Vol. 4. No. 1. Maret 2019

walaupun

http://ejournal.stikesbuleleng.ac.id/index.php/Midwinerslion | 54 
umpanya saya sedih sekarang, biargimana, nangisnya saya, biar anak enggak tahu”

Dibalik perasaan sedih, stress yang dialami setiap ODHA, beberapa cara bisa dilakukan ODHA dalam menerima penyakitnya, hal ini dapat berdampang baik bagi kondisi psikologis ODHA, cara-cara yang dilakukan oleh ODHA agar dapat menjalani hidupnya biasanya dengan cara tetap bersyukur dibalik penyakit yang diterima

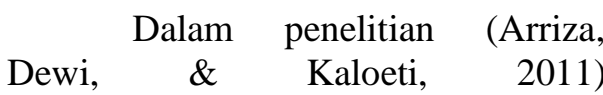
mengungkapkan bahwa beberapa faktor yang dapat mempengaruhi kebahagian dalam mekanisme koping yang postif diantaranya karena faktor internal dan eksternal. Faktor internal biasanya karena dari dirinya sendiri, setiap ODHA akan tumbuh dalam fikirannya untuk melakukan cara agar dapat melupakan penyakit yang diterima baik dalam segi bersyukur maupun melakukan hal-hal yang lebih positif, sedangkan dari faktor eksternal biasanya karena adanya faktor dukungan dari keluarga maupun dari masyarakat sekitar, hal ini dapat menimbulkan mekanisme koping yang positif pada setiap ODHA.

\section{f. Sikap tertutup yang serta kegiatan yang dilakukan untuk melupakan penyakit yang dialami}

P5 : "Yaaa dengan cara cari-cari kesibukan sihh..kalau saya di kampong kan gampang, modelnya menyibukan diri dahh.. pertama kalau baru bangun, iseng iseng olahragalahh.. cari keringat, apa namanya kalau udah sudah sibuk, fikirankan gini, gimana caranya saya harus semangat, harus sehat, walaupun saya sakit seperti ini, jadi saya harus bias"

P4: "Sekarang belum dulu, maaf dulu, untuk kedepannya nanti aja yaa..kalau sekarang belum, alasannya yaa itu ajaalah nanti kok bias nanti saya yaa tidak tahu yaa, masihh gini itu, nanti saya merasa disisihkan, dikucilkan, eemmm soalnyakan sakitnya gini"

Setiap ODHA berhak untuk menjaga privasinya sendiri, hal ini dilakukan biasanya untuk menghindari deskriminasi dari keluarga dan masyarakat. Dalam sikap tertutup seorang ODHA, akan membuat dirinya terhindar dari bentuk pengucilan, karena masyarakat sekitar akan tetap menganggapnya sebagai orang yang sehat.

Disamping sikap tertutup, beberapa kegiatan juga dilakukan oleh setiap ODHA dalam melupakan penyakit yang derita, beberapa kegiatan yang dilakukan biasanya dengan cara tetap bekerja atau mencari kesibukan, hal itu lah yang biasanya dilakukan oleh setiap ODHA, tindakan ini akan membuat ODHA melupakan masalah yang sedang dihadapi.

\section{KESIMPULAN}

Kesedihan serta perasaan takut meninggal yang dirasakan saat mengetahui penyakit yang dialami, dengan sub tema perasaan sedih, kaget dan syok saat mengetahui positif HIV, perasaan menyesal dan marah terhadap penyakit yang dialami, perasaan sedih, kecewa dan rasa tidak nyaman saat mendapat tekanan dari keluarga serta masyarakat, dan perasaan takut meninggal karena penyakit yang dialami

Bentuk deskriminasi dan pengucilan dari keluarga serta lingkungan masyarakat, dengan sub tema bentuk deskriminasi atau pengucilan dari keluarga, dan bentuk deskriminasi atau pengucilan dari lingkungan masyarakat

Penerimaan dan dukungan dari masyarakat terhadap penyakit yang dialami, dengan sub tema bentuk penerimaan dan dukungan dari keluarga terhadap penyakit yang dialami, bentuk penerimaan atau dukungan dari lingkungan masyarakat, serta sikap terbuka kepada keluarga dan masyarakat terhadap penyakit yang dialami

Perasaan putus asa dalam menjalani terapi, serta efek samping yang ditimbulkan dari obat ARV, dengan sub tema efek samping yang timbul setelah mengkonsumi obat ARV, dan 
perasaan pesimis atau putus asa dalam mengkonsumsi obat ARV

Mekanisme koping positif untuk menjalani hidup setelah terkena penyakit yang diderita, dengan sub tema perasaan bersyukur setelah terkena penyakit yang dialami, dan perasaan bahagia dan semangat dalam menjalani hidup

Sikap tertutup yang serta kegiatan yang dilakukan untuk melupakan penyakit yang dialami, dengan sub tema kegiatan yang dilakukan untuk melupakan penyakitnya, dan sikap tertutup kepada keluarga dan masyarakat terhadap penyakit yang dialami

\section{SARAN}

Hasil penelitian ini bisa menjadi pedoman sebagai wadah berkumpulnya orangorang yang terdiagnosis HIV/AIDS, dan bisa meningkatkan mutu dalam kegiatan pendampingan kepada ODHA yang telah bergabung di Yayasan.

\section{DAFTAR PUSTAKA}

Arriza, B. K., Dewi, E. K., \& Kaloeti, D. (2011). Memahami rekonstruksi kebahagiaan pada orang dengan hiv/aids (odha). Jurnal Psikologi Undip, 10(2), 153-160. https://doi.org/10.14710/JPU.10.2.15 3- 162

Creswell, J. . W. (2014). Penelitian Kualitatif \& Desain Riset. (S. Qudsy, Ed.) (3rd ed.). Yogyakarta: Pustaka Pelajar.

Gusti, R., \& Farlina, M. (2015). Studi Fenomenologi Pengalaman Orang Hiv/Aids (Odha) Dalam Mendapatkan Dukungan Keluarga Di Yayasan Lantera. Jurnal Ners, 11(1), 22-31.

Handayani, S. (2017). KALANGAN PECANDU NARKOBA SUNTIK Health Seeking Behavior and Antiretroviral Theraphy among Injecting Drug Users Who Living with HIV / AIDS.

Nur, Hasanah Hasna, S., \& Ika, H. (2012). Konsep diri orang dengan HIV dan AIDS (ODHA) yang menerima label negatif dan diskriminasi dari lingkungan sosial. Psikologia-Online:
Jurnal Pemikiran Dan Penelitian

Psikologi, 7(1), 29-40.

Retrieved from

http://jurnal.usu.ac.id/index.php/psikolog ia/article/view/400/377

Rahakbauw, N. (2016). DUKUNGAN

KELUARGA TERHADAP

KELANGSUNGAN HIDUP ODHA

(ORANG DENGAN HIV/AIDS) Oleh

Nancy Rahakbauw*. Insani, 3(2), 65-82.

Retrieved from stisipwiduri.ac.id

Risnawati. (2018). Pengalaman Klien Saat

Pertama Kali Terdiagnosis HIV/AIDS Di

LSM Mercusuar Riau Studi

Fenomenologi, 9(1), 9-15.

Sarikusuma, H., Herani, I., \& Hasanah, N. (2012). Konsep Diri Orang dengan HIV 
dan AIDS (ODHA) yang menerima

Label Negatif dan Siskriminasi dari Lingkungan Sosial. Psikologia Online

(Vol. 7).

Yuniar, Y., Handayani, R. S., \& Aryastami, N. K. (2011). Faktor- faktor Pendukung Kepatuhan Orang Dengan HIV/AIDS (odha) Dalam Minum Obat Antiretroviral Di Kota Bandung dan Cimahi. Penelitian Kesehatan, 41. No. 2, 1-12.

https://doi.org/10.1002/da.20849 